\title{
Pärimusliku ainese teke ja areng Perekoolis ning selle avaldumisvormid
}

\begin{abstract}
Reeli Reinaus
Teesid: Artikkel käsitleb folkloori levimist, vastuvõttu ja esinemisvorme Interneti-keskkonnas. Uuritav materjal pärineb Interneti-portaali Perekool.ee foorumitest.

Artikli esimeses pooles vaatlen pärimuse levikut ja arengut foorumites ning sellega seonduvaid erinevaid käitumismustreid. Samuti toon välja, kuidas erineb suhtumine homogeensesse materjali lähtuvalt selle esitamisviisist. Näiteks paljudel juhtudel sõltub pärimusliku ainese omaksvõtt foorumeis kontekstist. Väljend vanarahvatarkus võib iseenesest olla keskkonnas nii negatiivse kui ka positiivse värvinguga. Teiseks kaardistan pärimusliku ainese esinemiskujud ja funktsioonid.

Et Interneti-foorumid on suunatud paljuski suhtlemisele ja meelelahutusele, siis on suur just anekdootide ja muu humoorika ainese osatähtsus. Samuti esineb rohkelt usundilist materjali - alates raseduseaegsetest ennetest ja lõpetades linnajuttudega.
\end{abstract}

Märksõnad: folkloor, folkloorižanrid, Internet, rahvatarkus, pärimuse edasikandumine

\section{Sissejuhatus}

Interneti levikuga on muutunud inimeste omavaheline suhtlemine. Internet võimaldab lävida inimestega, kes asuvad geograafiliselt kaugel või siis koonduda lähtuvalt huvist mitmesugustesse jututubadesse või foorumitesse, mis ühendab ühesuguste huvidega, kuid reaalses elus võõraid inimesi. Koos Interneti kättesaadavuse suurenemisega on sealses keskkonnas levivas infos järjest kasvanud folkloorse ainese osatähtsus.

Internet on loonud uusi võimalusi ka uurijatele. Interneti uurimist liigitavad teadlased reaalmaailmas välitööde alla (Dicks \& Mason 1998; Runnel 1999: 19). Interneti uurimise populaarsus on ilmselt tingitud selle lihtsusest ja mugavusest, sest kogukonnad ületavad geograafilisi piire, füüsiline kohalolek pole 
vajalik ja lisaks iseloomustab neid kõrge spetsialiseerumine - seega on võimalus uurida väga erinevaid rühmi ja subkultuure (Reinaus 2007: 29). Internetiuurija John R. Suler toob oma artiklis välja Internetti iseloomustavad jooned, mis on abiks ka uurijatele - identiteedi paindlikkus, anonüümsusest tingitud võrdne staatus, sotsiaalne mitmekesisus ning aja ja ruumi transtsendentsus (Coomber 1997; Suler 1999). Samuti saab uuritava info salvestada. Internet mõjub ka psühholoogilisele barjäärile nõrgendavalt - Interneti vahendusel räägitakse julgemalt ja vastatakse ka delikaatsematele küsimustele (Suler 1996a; Runnel 1999: 26-27).

Perekooli foorumites võib kohata hulgaliselt erinevat folkloorset ainest. Lisaks folkloori žanrilisele liigitamisele ja iseloomustamisele tekkis mul huvi ka selle vastu, kuidas pärimus tekib ja areneb foorumi keskkonnas ning milline on selle vastuvõtt.

Artikli esimeses pooles vaatlen pärimuse levikut ja arengut Perekooli foorumites ning erinevaid käitumismustreid sellega seoses. Samuti toon välja, kuidas erineb suhtumine homogeensesse materjali lähtuvalt selle esitamisviisist. Teiseks püüan kaardistada pärimusliku ainese alla liigitatava materjali esinemiskujud ja funktsioonid.

Uuritav materjal pärineb Perekooli Lapse ootamise, Sünnituse, Beebi, Lapse arengu ja Pereelu foorumist ning peamiselt on kasutatud aastail 2002-2005 kirja pandud ainest.

Eesti Ämmaemandate Ühingule kuuluv portaal Perekool.ee loodi Avatud Eesti Fondi toel ning avalikkuse ette jõudis see 2000. aasta suvel. Perekool on mõeldud eelkõige neile, kes planeerivad pere juurdekasvu, ootavad last või on juba lapsevanemad. Samuti pakub see vajalikku teavet, toetust ja nõustamist alates meditsiinilistest konsultatsioonidest kuni igapäevaelu nõuanneteni. Lisaks pakutavale infole on Perekoolil ka vestlusring, mis koosnes uurimuse tegemise ajal kümnest erinevast foorumist - Rasestumine, Lapse ootamine, Sünnitus, Imetamine, Beebi, Mitmikud, Lapse areng, Isad, Pereelu ja Muud teemad. Praegu (2007. aastal) on neid viisteist. Lisandunud on foorumid Tööelu ja pere, Kööginurk, Muude teemade elujõuline foorum, Tulipunkt! Foorumi abi ja mõtted. Pereelu on andnud ainest koguni kahele foorumile: Pereelu mõtete vestlusring ja Pereelu ajaviitejutud. Perekooli kasutajate karakteristikuid on foorumi anonüümsuse tõttu raske tuvastada, kuid tõenäoliselt on neil inimestel enam-vähem regulaarne juurdepääs Internetile ja nad on eeskätt noored lapsevanemad või lapsevanemaiks saamas (Reinaus 2007: 18). 


\section{Interneti-keskkonna iseärasused. Pärimuse levik.}

\subsection{Virtuaalsed kogukonnad}

Virtuaalsed- ehk küberkogukonnad on muutunud tänapäeval paljudele sotsiaalse koostoimimise esmaseks vormiks, kus veedetakse suur osa oma päevasest ajast (Thomsen \& Straubhaar \& Bolyard 1998; Suler 2000). Sotsioloog Ray Oldenburg on väitnud et online-kogukonnad täidavad tühimikku, mis on levinud tänapäeva ühiskonnas, kus lähedus ja sotsiaalsed sidemed on muutunud haruldaseks. Teoses Virtual Community osutab Howard Rheingold, et e-maili vaatamine või logimine jututuppa tähendab sama, mis astuda sisse mõnda kohvikusse, et vaadata, kes seal on ja kas selle inimesega soovitakse rääkima jääda. Ka Rheingold ütleb, et virtuaalsete kogukondade populaarsus on tingitud sellest, et inimeste elus on vähe avalikke kohti, kus nad saaksid teistega segamatult suhelda (Rheingold 1998). Suler (1996a) märgib samuti, et enamasti on Internetis kõigil võrdne võimalus sõltumata staatusest, rassist, soost jne endast märku anda. Sellist võimalust nimetatakse võrgudemokraatiaks (ingl net democracy). Kogukonnad kannavad ka meelelahutuslikku funktsiooni, sest Internet on muutunud paljudele samasuguseks lõbustusvormiks nagu näiteks teleri vaatamine.

Argisuhtluse käigus luuakse ja edastatakse virtuaalsetes kogukondades ja suhtlusrühmades ka oma olemuselt folkloorset teavet. Sellekohase terminina on kasutusele võetud sõna arvutifolkloor, mille all peetakse silmas nii arvutikasutajate loodud, kui ka arvutite abil levivat folkloori (Jordan 1997: 140). EloHanna Seljamaa (2000) on liigitanud selle alla nii elektrooniliselt levivad ahelkirjad, naljad, interaktiivsed mängud, hoiatused arvutiviiruste eest, kui ka folklooriilmingud. Enamasti on arvutifolklooril olemas vasted varasemas pärimuses, muutunud on lihtsalt selle levimisviis.

\subsection{Pärimusliku ainese teke ja areng Perekooli foorumites}

Perekoolis nii omandatakse kui ka jagatakse infot, foorumites levivad nii vanad kui ka uued uskumused, õpetused ja ideed. Järgnevalt vaatlen pärimusliku ainese teket ja positsiooni Perekoolis. Artiklis pean pärimusliku ainese all silmas nii traditsioonilisi kui ka uusi uskumusi, endeid või ka usundilisi muistendeid. Samuti rahvameditsiiniga seonduvat. Pärimusliku ainese tekke- ja arenguskeemi foorumeis olen jaotanud nelja etappi. 


\section{Küsimus või väide}

Teemaalgataja esitab küsimuse või väite, millele ta soovib otsest vastust või vähemalt kaasvestlejate kommentaare. Enamasti on küsija dilemma ees - kas uskuda kelleltki (tavaliselt lähedaselt vanemalt sugulaselt) kuuldud ennet või uskumust. Ta soovib kuulda teiste sarnases situatsioonis olevate inimeste arvamusi või analoogseid kogemusi, mis peaksid küsija võimalikku käitumist kallutama kas siis ühele või teisele poole. Teinekord asendab küsimust ka konkreetne hoiatuslugu ehk siis enamasti isiklik usundiline kogemusjutt, kus kirjutaja püüab isikukogemuse narratiivi kaudu veenda teisi õigesti käituma.

Iseloomulik on see, et paljudel juhtudel tunduvad küsimused olevat esitatud lihtsalt igavuse peletamiseks ja meelelahutuseks, isiklik seos teemaga võib olla üsna nõrk. Siinkohal sobib näiteks teema, kus soovitakse teada, kas raseduse ajal nähtud uni, kus lapsega midagi juhtub, on hiljem ka täide läinud. Samas ei ole teemaalgatajal vähemalt enda väidete põhjal teemaga midagi ühist, ta uurib seda huvist paranormaalsete nähtuste või folkloori vastu. Tema teemaalgatus seevastu kutsub esile arvukalt kommentaare inimestelt, kelle enda või mõne lähedasega on selline juhtum aset leidnud.

\section{Kommentaarid}

Järgmine etapp pärimusliku ainese foorumis liikumise teel on see, kui küsimust, väidet või kogemuslugu hakatakse kommenteerima. Selleks on mitmeid võimalusi.

Kõigepealt võidakse kommentaarides eitada suhet teemaga või usku sellesse - seega pole vastajal sellelaadset kogemust ja ta eitab ka nähtuse võimalikkust.

Teiseks aktsepteeritakse küll esitatud folkloorset uskumust, kuid nii kirjutajal endal kui ka tema lähedastel puudub vastav kogemus.

Kolmandaks usutakse konkreetset ennet või uskumust, ja tuuakse näiteks ka omapoolne kogemuslugu, mis kannab seega enamasti nii teavitavat või ka hoiatavat funktsiooni. Viimasel juhul ei usu kommenteerijad küll antud väidet, kuid neil on siiski selle nähtusega haakuv kogemus - seda püütakse seletada teisiti, enamasti ratsionaalset maailmavaadet kasutades. Erapooletuid kommentaare peaaegu polegi.

\section{Diskussioon}

Kolmanda etapina järgneb teemaalgatusele üleüldine diskussioon esitatud uskumuste ja kogemuslugude tõeväärtuse üle. Selle käigus püütakse oma või kellegi lähedase isikukogemuse narratiivi abil teisi veenda. Vastukaaluks aga 
tuuakse välja hulganisti teaduslikke seletusi, kirjutaja silmis autoriteetsete isikute seisukohti ja samalaadseid juhtumeid, mis on lõppenud hoopis teistmoodi. Sõltuvalt teemast võivad sellised diskussioonid paisuda üpriski tulisteks sõnavahetusteks.

\section{Pärimuse kaasavõtt}

Viimaseks etapiks võib pidada pärimuse aktualiseerumist uute inimeste silmis ja selle Perekoolist nö kaasavõtmist. Kas pärimusliku ainese tõeväärtuse poolt- või vastuargumendid veensid lugejat või mitte, pole oluline, sest igal juhul jääb passiivne teadmine inimese alateadvusse ja võib analoogses situatsioonis aktualiseeruda. Teadmine pärimusest ei pruugi küll panna inimest vastavalt sellele käituma, kuid sõltuvalt juhtumist võib see tekitada temas kõhklusi, mis omakorda sunnivad teda jällegi foorumist nõu küsima või loovad tahtmise proovida, kas loetul on tõepõhi all.

\subsection{Suhtumine pärimuslikku ainesesse}

Järgmisena toon välja erinevad suhtumisviisid pärimusse Perekoolis. Olen need jaganud viide rühma, mida järgnevalt iseloomustan.

\section{Segaduses olek}

Et teemaalgatajal puudub autoriteetne allikas, mis annaks ta küsimusele vastuse ja kinnitaks või lükkaks ümber mõne uskumuse, tuleb ta nõu küsima Perekoolist. Kuigi paljud kirjutajad kinnitavad juba teemat algatades, et nad ei usu esitatavat väidet, soovivad nad siiski teada ka teiste arvamust. Seega peab paika väide, et kriisisituatsioonis võib aktiviseeruda latentne teadmine ning tekitada opositsiooni inimese ratsionaalse ja intuitiivse mõtlemise vahel.

\section{Pärimuse naeruvääristamine}

Tihti kutsuvad juba sõnad vanarahvatarkus või rahvapärimus foorumeis esile tugevalt negatiivse hoiaku, enamasti väidetakse, et see on vananaisteloba. Ende uskumist eeldab vaid kirjutaja või mõne tema tuttava ennet kinnitav kogemus. Eeskätt on igasugusest naeruvääristamisest hoolimata visad püsima kunagised rasedusega seotud tegevuskeelud. Mõne teema puhul on siiski märgata ka pärimusliku ainese tunnustamist ja väärtustamist, sest see esindab traditsioonilist elustiili. 
Ennete eitajaid tundub ajendavat soov kaitsta enda silmis turvalist ja kõike äraseletavat ratsionaalset maailmavaadet. Millegi üleloomuliku uskumine ei sobitu inimese maailmapilti, sellepärast püüab ta seda eitada, mitte küll ebaratsionaalset uskumust ümber lükates, vaid pidades kaitsekõnet teaduslikele seletustele. Paljuski on selline käitumine tingitud asjaolust, et foorumis esitatakse rohkelt seisukohti, mis tunduvad tänapäeva ratsionalistliku maailmavaate seisukohalt naeruväärsed. Näiteks olgu toodud uskumus, et kui naine raseduse ajal alkoholi tarbib, siis kasvab lapsest joomar (Lapsest kasvab joomar? - http://w.perekool.ee/foorum/read.php?f=7\&i=615202\&t=615175) või et kui lapse kantud riided ära müüa, kaob nendega koos ka lapse õnn (Lapse asju müües, müüd õnne ära - http://w.perekool.ee/foorum/read.php?f=7\&i= $610467 \& \mathrm{t}=610306)$.

\section{Pärimuse aktsepteerimine}

Kolmandana tooksin välja hoiaku, mille esindajad traditsioonilisi teadmisi oma elus küll ei rakenda, kuid tunnustavad seda kui esivanemate tarkust. Samuti eeldatakse, et nii mõnelgi endel võib tõepõhi all olla, kuid ise ei olda varmad seda katsetama. See suhtumistasand annab kindlasti tõuke rakendada traditsioonilist tarkust, kui selleks tekib tarvidus ja soodne olukord.

\section{Pärimuse väärtustamine ja rakendamine}

Viimastel aastatel väärtustatakse foorumites üha enam rahvameditsiini - propageeritakse ravimteesid, vanu ravivõtteid, maalähedast toitumist. Sellele lisandub sümpaatia alternatiivmeditsiini vastu: aktiivsünnitus, homöopaatia ning rahvaarstide seisukohtade ja nende praktika arutamine. Miks rahvatarkust väärtustatakse, on huvitav küsimus. Ilmselt nõuaks see pikemat uurimist ja ühest vastust sellele anda ei saagi. Kuid tundub, et osa inimesi hindab seda seetõttu, et nende arvates elasid inimesed traditsioonilises ühiskonnas harmoonilisemalt, kooskõlas oma sisemaailma ja ümbritseva loodusega. Teisalt on neil kindlasti soov vastandada ennast tänapäeva tehnoloogilise ja keemiarohke eluga.

\section{Ambivalentsus}

Paljudel juhtudel sõltub nähtusse suhtumine sellest, kuidas, kes ja millega seoses seda esitab. Suhtumine vanarahvatarkusse on sõltuvalt teemast foorumites erinev. Ühelt poolt peetakse seda igandiks, mis vaid foorumit risustab 
ning sellest räägitakse irooniaga. Teisalt aga on selle väljendiga tähistatud vanad ravivõtted ja maailmavaade paljude silmis populaarsed ja sageli küsitakse, kas keegi teab, mida tegid esiemad ühe või teise probleemi korral.

Seega ilmneb, et pärimuslikku ainesesse ei suhtuta kui nähtusse omaette, vaid pärimusega käib kaasas kontekst, mis kas leiab või ei leia vastuvõttu. Paljudel juhtudel on see mõne inimese kogemuslugu, mis kaasvestlejaid mõjutab, mõnikord üldine kontekst, mille raames pärimusest räägitakse. Materjali põhjal tundub, et foorumites püütakse sageli juba automaatselt väärtustada kõike, mis on traditsiooniline ja vastandub nii ametliku meditsiini kui ka tänapäevase tehnoloogiaga. Seega ei ole traditsiooniline tarkus väärtus seetõttu, et see on vana, vaid seetõttu, et see pole uus.

\subsection{Kokkuvõtteks}

Infovahetusele keskendunud kogukondi võib nimetada ekspertvõrgustikeks, sest sellistes rühmades kerkivad esile asjatundjad, kes vastavat valdkonda hästi tunnevad või näivad tundvat. Neid isikuid tunnustatakse autoriteetidena ja tihtipeale antakse neile omavahelises suhtluses rohkem õigusi kui teistele (Oja 2005). Autoriteetide sõnavõttudest on võimalik teada saada, millised tegevused, mõtteviisid või ellusuhtumised on hetkel populaarsed ja aktsepteeritavad, millised taunitavad. Rühmas domineerivaid seisukohti püütakse seejärel kas kohandada oma mõttemaailmaga, et joonduda rühma peasuuna järgi või neile vastanduda (Lampel \& Bhalla 2007).

Kuigi paljud kirjutajad kinnitavad juba teemat algatades, et nad tegelikult ei usu esitatava väite paikapidavust, soovivad nad siiski teada ka teiste arvamust. Niisiis peab paika väide, et ollakse latentse pärimuse kandjad, kusjuures pärimus võib kriisisituatsioonis aktiviseeruda ning tekitada opositsiooni inimese ratsionaalse ja intuitiivse mõtlemise vahel.

Perekoolis levivad uskumused peamiselt põlvkonna-siseselt. Vanasti kandusid teadmised üldjuhul vanematelt põlvkondadelt noorematele. Tänapäeval vanemaid inimesi uskuda ei taheta, eelistatakse kuulda (lugeda) eakaaslaste kogemusi. Kui vanematelt kuuldut kinnitab eakaaslase kogemuslugu, võetakse uskumus siiski võimaliku variandina arvesse. Seega on Perekool ise nii ennete ja uskumuste taastootja kui ka uute nähtuste levitaja. 


\section{Pärimus Perekoolis}

Info otsimise ja nõu küsimise kõrval on Perekool koht ka kogemuste jagamiseks ning ostu- ja müügitehingute sooritamiseks. Foorumeis leiab aeg-ajalt aset ka sotsiaalsete kontaktide loomine - lastele mängukaaslaste ja emadele jalutuskaaslaste või kirjasõprade otsimine (Otsin emmesid tartust - http:// w.perekool.ee/foorum/read.php?f=7\&i=660336\&t=660101). Üheks oluliseks Perekooli foorumite funktsiooniks on meelelahutus.

Et lastega kodus olevatel emadel, kes on kahtlemata Perekooli peamine sihtrühm, on vajadus suhelda sageli suurem kui seda reaalne elu võimaldab, vajatakse sarnaste huvidega inimeste seltsi virtuaalkogukondades. Seega on mõistetav, et oma aega foorumeis püütakse sageli sisustada meelelahutuslike teemade või küsitlustega. Küsitluste puhul võib märgata koguni omalaadset uurija-aspekti - suure kogukonna puhul on hea võimalus küsijat huvitavatele teemadele vastust saada. Näidete arv võib siinkohal olla lõputu - alates laste nimedest (teate oma lapse nime tähendust? - http://w.perekool.ee/foorum/ read.php?f=6\&i=733287\&t=733033), pikkusest-kaalust kuni kasutajate elukaaslaste (on teie meeste nimed? - http://w.perekool.ee/foorum/read.php?f=6\&i= 367410\&t=367184) ja enesekohase infoni välja.

Samuti tehakse mõnikord ettepanek panna üles ühevanuste laste pildid või mõnel muul moel ühise nimetaja alla kuuluvad fotod. Viimasel ajal esinevad sellised üleskutsed ka rasedatele (kõhupilte:) - http://w.perekool.ee/foo$\mathrm{rum} / \mathrm{read}$.php?f=2\&i=633966\&t=633922).

Meelelahutuslikul eesmärgil levitatakse foorumeis ka palju folkloorset ainest - kirjutatakse juhtumustest, mis on kirjutaja enda või tema perekonnaliikmega aset leidnud (väike naljakas vestlus - http://w.perekool.ee/foorum/ read.php?f=7\&i=619336\&t=619300). Samuti pannakse üles linke naljakate või üllatavate piltide ja animatsioonidega või näiteks Rate.ee keskkonnast võetud fotodega. Sellisel juhul antakse fotololijale tavaliselt kas ülimalt positiivne või siis ülimalt negatiivne hinnang. Palju esineb foorumites ka anekdoote ja kasutajate endi kirjutatud meelelahutuslikku loomingut.

Et ka klatši peetakse üheks folkloori eriliigiks, võib kuulujutudki lugeda Perekoolis esineva pärimuse hulka. Peamiselt levitatakse kuulujutte tuntud avaliku elu tegelaste, kuid ka Perekooli enda kasutajate kohta. Viimased annavad sageli selleks ise rohkelt ainest, tekitades teadlikult mõttevahetusi, kus nad püüavad pälvida oma isikuga kaasvestlejate tähelepanu. 


\subsection{Ended ja uskumused}

Traditsiooniliselt on olulise sündmuse puhul inimelus, mida rasedus kahtlemata on, levinud kaks peamist käitumisviisi - seda püütakse märkide abil ennustada ja nähtuse kulgu endale võimalikult soodsaks muuta. Perekoolis levivad uskumused ja ended on seotud enamasti lapse eostamise, soo ennustamise ning ema meeleolu ja käitumisega raseduse ajal. Samuti on olulisel kohal sünnituse esile kutsumise ja vastsündinu sünnimärkidega seotud tähelepanekud.

Last ootava naise üks soove on teada saada, mis soost last ta ootab. Kuigi seda saab tänapäeval meditsiiniliselt suhteliselt varakult kindlaks teha, pole kuhugi kadunud ka vanad ennustusviisid. Nii mõnigi kord püütakse siduda teadasaadut levinud uskumustega või hoopis endeid ümber lükata.

Ennustamise viise on väga erinevaid - usutakse vanu endeid, kuid levivad ka paljud uued läänest üle võetud uskumused. Et teema on jätkuvalt aktuaalne, seda näitavad aina uuesti ja uuesti esitatavad küsimused (Kõhukuju ja lapse sugu - http://w.perekool.ee/foorum/read.php?f=2\&i=888398\&t=888393; Kas siin on keegi, kes oskaks kõhu järgi ennustada lapse sugu? - http://w.perekool.ee/ foorum/read.php?f=2\&i=846171\&t=845663).

Vanade uskumuste seas domineerivad endiselt ennustamine raseda välimuse ja kõhu kuju järgi. Samuti praktiseeritakse pendliga ennustamist. Uuemaid ja keerukamaid uskumusi, mida esitatakse seoses lapse soo ennustamisega, on üllatavalt palju. Üks levinuim on lapse soo ennustamine Hiina kalendri järgi (Hiina kalendi järgi lapse sugu.... - http://w.perekool.ee/foorum/ read.php?f=2\&i=1192163\&t=1191771). Seda iseloomustab uskumus, et lapse sugu sõltub sellest, kas eostamise hetkel on noorem veri mehel või naisel. Naise veri vahetub iga kolme ja mehe veri iga nelja aasta tagant. Seega tuleb naise vanus eostamise hetkel jagada kolmega ja mehe vanus neljaga - kellel on saadud arvu taga väiksem komakoht, sellega ühest soost laps sünnib. Teema tekitab alati suurt vastukaja ja inimesed esitavad foorumis aruandeid, mis soost lapse nad kui vanalt said. Ilmselt on see oma keerukuse tõttu üldse kõige rohkem poleemikat tekitanud ennustusviis, sest kasutusel olevaid Hiina kalendreid on väidetavalt nelja sorti ja arvutamine tekitab enamasti segadust.

Selliseid uskumusi leidub veel - näiteks kellaaja teooria puhul usutakse, et kõik lapsed sünnivad ühte perre umbes samal kellaajal. Samuti on levinud uskumus, et naine võib rasestuda vaid ühel päeval kuus ja seega peaksid kõik ühe pere lapsed olema sündinud samadel või lähestikku olevatel kuupäevadel. Või ka, et emal ja tema esimesel lapsel peaks olema mingil põhjusel sünnipäev 
lähestikku. Erandina võivad olla lähestikku ka lapse ja isa või mõne lähisugulase sünnipäev.

Veel üks teooria sünnipäevadest

Autor: Jk

Kuupäev: 09-12-02 23:33

Aegade jooksul jäänud silma selline kokkusattumus (?!) -> Emal ja tema esimesel lapsel on sünnipäevad lähestikku. Eranditena ehk siis ka lähestikku sünnipäevad isa või mõne muu lähisugulasega. Sellist kokkusattumust esineb nii enda kui abikaasa suguvõsas sagedasti (http:// w.perekool.ee/foorum/read.php?f=6\&i=79046\&t=78944).

mitmelapselised - teooria?

Autor: Melody

Kuupäev: 09-12-02 22:30

Lugesin kuskilt, et naine võib rasestuda vaid ühel päeval kuus? Tekkis sportlik huvi, et mis on teie laste sünnikuupäevad? Kas on nii lähestikku, et võiks lugeda teoorial olevat miskit tõepõhja all? Mul on - 14, 16 ja 17 kuupäevad ;) (http://w.perekool.ee/foorum/read.php?f=6\&i=78917\&t= 78916).

Ended ja nende järgimine tekitavad palju vastakaid arvamusi, sest kuigi nad levivad foorumis peamiselt meelelahutuslikul eesmärgil, on kirjutajail tihtipeale hirm, mis saab siis, kui ta on ühe või teise keelu vastu eksinud - kas läheb nii nagu ennustus ütleb või siiski mitte. Seega leiab foorumis nii nende halvustamist, kui ka positiivsemat suhtumist (Vananaiste tarkused:D - http:/ /w.perekool.ee/foorum/read.php?f=2\&i=777577\&t=777494).

Traditsiooniline uskumus ütleb, et raseduse esimesel kolmandikul ei tohi sellest rääkida, sest siis võib lapsega midagi juhtuda. Samuti on usutud, et suuremaid lapse asju (vanker, voodi jne) pole vaja enne tuppa tuua või üles panna, kui laps on sündinud, sest alles siis saab olla kindel, et lapsega on kõik korras (Mikkor 2000: 811-812).

Tädi tuli meile täna külla. Kraamisin just kappi ja rääkisin et peaks osa tirtsu asju maha müüma, kapp ajab juba üle ääre. Tädi aga ütles ehmunud näoga, et lapse asju ei tohi müüa. Et niimoodi müüd lapse õnne maha? Ütlesin küll, et mis jama sa ajad, aga nü̈̈d jäi ikka kuhugi kõrvataha kripeldama... Te usute? (http://w.perekool.ee/foorum/ read.php?f=7\&i=610467\&t=610306). 
Ka leidub Perekoolis rohkesti teateid seoses laste asjade muretsemise ja lähedastele rasedusest rääkimisega. Teema aktuaalsust näitab see, et foorumis küsitakse, kuidas on teised sellises olukorras toiminud. Ja kuigi enamik vastab peamiselt, et nad ei usu seda ja pole kunagi nii toiminud, leidub alati keegi, kes räägib enda või mõne lähedasega juhtunud uskumust kinnitava loo, mis hoiab pärimust elusana.

Ebausuga seoses on üks levinuim uskumus veel see, et lapse ja nabanööri seisund sõltub ema käitumisest. Ometi pole läbi aegade suurimale hirmule et lapsel võib nabanöör ümber kaela minna - meditsiini seisukohalt leitud mingit alust (Traat 1990: 33). Ent küsimuse aktuaalsus näitab, et naised on kas tugevalt vanade uskumuste mõju all või muretsevad selle pärast üleliia (Nabanöör ümber kaela - http://w.perekool.ee/foorum/read.php?f=2\&i=694855\&t= 694803). Et uskumus on nii levinud, küsitakse selle kohta väga sageli, mis omakorda võib tekitada tunde, et kui sellest nii palju räägitakse, äkki see siis vastabki tõele.

\section{Unenäod}

Autor:liisu

Kuupäev: 30-10-02 16:24

Esimese lapsega nägin unes tüdrukut ja tuligi tüdruk. Nüüd olen näinud poissi ja UH ka kinnitab, et tuleb poiss.

Ja veel: viimasel ajal olen näinud ka oma endist boyfriendi, kellega suhtlesin viimati 6 aastat tagasi. Ei tea, mis see küll peaks tähendama? (http://w.perekool.ee/foorum/read.php?f=2\&i=102038\&t=102034).

Ebausu alla kuuluvad kindlasti ka märgid ja defektid, mida võidakse vastsündinult leida (Lapsel kurenokajälg - http://w.perekool.ee/foorum/read.php?f=2\&i= 727361\&t=727293). Kaasasündinud märgid ja vead on inimesi alati huvitanud, tekitades kas vastikust või müstilist oudustunnet, kirjutab Tartu Ülikoolis kaitstud diplomitöös Tänapäeva sünnikombestikust. Rasedusaegsed uskumused Merike Traat (1990). Kõik see tekitab soovi nähtust seletada, annab toitu fantaasiale, levitades uskumusi ja valearusaamu. Märkide ja defektide tekkimisega seonduvad eelkõige rasedusaegsed tabud, mille rikkumine võib veel sündimata last mõjutada. Märkide kohta kogutud materjal jaguneb kaheks: hoiatused ja keelud mõjude eest, mis võivad märke tekitada ning juba tekkinud konkreetsed märgid, mida seletatakse ema poolt raseduse ajal kogetu mõjuga. Teises rühmas on valdavalt väga konkreetsed sündmusekirjeldused konkreetsete märkide kohta. Seost märgi ja kogetu vahel peetakse otseseks ja kindlaks. 
Perekooli foorumis Lapse ootamine arenevad sageli diskussioonid erinevate rahvalike ennustusviiside ja nende paikapidavuse üle - paljudel juhtudel teatatakse kohe teema pealkirjas - Ennustage mulle! - ning seejärel tuuakse välja oma rasedust iseloomustavad rahvalike ennustusviiside võimalikud parameetrid (vananaiste loba kuulda;) - http://w.perekool.ee/foorum/read.php?f= $2 \& \mathrm{i}=755495 \& \mathrm{t}=755495$ ). Leian, et sellise käitumise kaks võimalikku tegutsemismotiivi on ühelt poolt vaba aja sisustamine ja teisalt soov testida vanarahva uskumusi, sest üldjuhul tunnevad inimesed seletamatute nähtuste vastu suurt huvi.

\subsection{Rahvameditsiin}

Perekool on paljude silmis kahtlemata autoriteetne vastuste allikas. Vestlusringist otsitakse varasemaid kogemusi ja toetumist traditsioonilisele tarkusele. Vähem usutakse erialaspetsialiste, rohkem neid, kes on ise läbi elanud samasuguse juhtumi. Teiste kasutajate sarnaste kogemuste lugemine annab tõenäoliselt hea ülevaate kogu teemast, võimalikest tegutsemisviisidest ja nende tagajärgedest. Samas annab see inimesele võimaluse kirjutada oma kogemusest lähtuv narratiiv, mis on kas teavitav, hoiatav või julgustav (Reinaus 2007: 22). Küberkogukondi iseloomustabki see, et nad jagavad infot, mis on kasutajate loodud, mitte näiteks spetsialistide või lehekülje haldaja oma (Ridings \& Gefen 2004).

Rahvameditsiiniga seotud teemasid leidub Perekooli foorumites seinast seina - siia alla kuuluvad nii ravimteede kasutamisõpetused kui ka erinevate rahvaravitsejate seisukohtade avaldamine. Väga populaarsed on alternatiivmeditsiini erinevad vormid - küsitakse nii uuemate suundade (homöopaatia) kui ka traditsiooniliste ravimisviiside kohta. Alternatiivmeditsiini alla kuulub samuti aktiivsünnitusliikumine, mille esindajad propageerivadki peamiselt rahvameditsiini tehnikaid ja raviviise.

\section{Nõmmlivivatee}

Autor: ootaja

Kuupäev: 06-11-03 14:06

perekoolis räägiti, et kui tahad, et sünnituse ajal nõmmliivatee mõjuks, siis küll ei tasu nädalaid varem seda tarvitama hakata. organism harjub ja mõju ei mingit (http://w.perekool.ee/foorum/read.php?f=2\&i= $237211 \& \mathrm{t}=235751)$.

Ravitsejatest on Perekoolis kahtlemata kõige enam kõneainet pakkunud Luule Viilma. Erinevad kirjutajad suhtuvad temasse erinevalt - sõna võetakse nii 
tema seisukohtade poolt kui ka vastu. Püütakse lahti seletada tema õpetust ning esitatakse konkreetseid kogemuslugusid. Samuti seostatakse ja võrreldakse tema seisukohti teiste alternatiivfilosoofidega (Gunnar Aarma, Carlos Castaneda, Anastasia, Vladimir Merge, Sai Baba jt).

Ilmselgelt on Perekool ka vanade raviviisidega seotud eelarvamuste murdjaks, ning et vanu ravimisvõtteid sageli enam ei usaldata, on järjest enam hakatud tundma huvi uuemate alternatiivsete raviviiside vastu, mis sageli polegi midagi uut, vaid pigem unustatud vana. Alternatiivmeditsiini populaarsuse juures võib rolli mängida ka see, et iseravimine on enamasti odavam ja kemikaalivabam kui arsti juures käia ja retseptiravimeid osta.

Jagage nippe, kuidas sünnitust esile kutsuda

Autor: Gessu 33

Kuupäev: 26-01-05 12:21

Basiilik, oregaano, piparmünt, kardemon, ingver ja kaneel võivad kutsuda esile sünnitust....soenda selga natuke.....ja korras.... (http:// w.perekool.ee/foorum/read.php?f=2\&i=539570\&t=538975).

\subsection{Linnajutud}

Internet on ka soodne linnalugude tekke- ja levikukeskkond, sest kui seni on see žanr levinud peamiselt suuliselt, siis Internet võimaldab nende levikut oluliselt kiirendada (Brunvand 1998). Lisaks sellele on Interneti leviku ja arvutikasutajate ringi laienemisega pidevalt suurenenud võrgus ringelevate linnalugude arv.

Elo-Hanna Seljamaa vaatleb oma proseminaritöös (2000) linnalugu Kallid koogid, mis ringleb elektronkirjade vahendusel. See lugu on tuntud ka Perekoolis. Loos jutustab minategelane, pankur Rain Lõhmus oma õhtusöögist kohvikus Võitlev Sõna, kus ta soovib saada talle maitsenud kookide retsepti. Retsept osutub oodatust kallimaks, kuid kohvik keeldub raha tagastamast ning kättemaksuks paneb minategelane koogi retsepti ja valmistamisjuhendi Internetti ringlema. Tegelikkuses on see rahvusvaheliselt hästi tuntud ja juba üsna vana e-kirja tõlge. Erinevused seisnevad vaid selles, et ingliskeelses originaalis on tegemist küpsistega ning nende eest makstav hind on väiksem, samuti pole minategelane tuntud (Seljamaa 2000).

Perekoolis on levinud ka teisi tuntud süžeega linnajutte - näiteks lugu kohvipulbrist, mis hiljem osutub kellegi sugulase maisteks jäänusteks, kuid suurt kõlapinda pole need omandanud. Pigem on rohkem kõneainet pakkunud Eestis aktuaalne temaatika - HI-viirus ja narkomaanid. Levinud on nii lood sellest, kuidas narkomaanid kaubanduskeskustes sidrunite sees süstlaid 
puhastavad, kui ka paar aastat tagasi laialt levinud lugu sellest kuidas IdaVirumaal, peamiselt Narvas torgatakse inimesi avalikes kohtades viirust kandva süstlaga. Viimane tekitas Interneti-kasutajate seas kohati suure paanika, sest juhtumeid, kus narkomaan süstlaga inimesi ähvardab, on varemgi ette tulnud ja seega on raske eristada väljamõeldist reaalsusest. Usutakse ka jutte, et kaupluste riietuskabiinides on turvakaamerad, mille abil riietujat jälgitakse; et kauplustes müüakse vanu tooteid ja nende sildid kirjutatakse uue kuupäevaga üle. Samuti on ette tulnud nõukogude perioodist tuntud lugusid. Näiteks võib tuua kas või jutu, mis räägib sellest, et vorstitoodetes on ka rottide liha - hommikul vorstitsehhis masinaid tööle pannes kostab nende vahele jäävate rottide kisa, kes samuti vorstiks tehakse.

\subsection{Lühivormid - argiarvamused, vanasõnad, kõnekäänud, ütlused}

Perekoolis on levinud ka tähelepanekud, mida võib klassifitseerida argiarvamustena. Termini argiarvamus alla mahub mitmeid folkloorseid nähtusi, kinnitab Leea Virtanen, märkides, et lõpuni antud ainest kategoriseerida on keeruline (1994: 22). Seega on ka minu uuritava materjali puhul väga raske öelda, mida peavad kirjutajad igapäevatarkuseks või mida levinud stereotüübiks, millele vestluses eriti tõsiselt ei viidatagi. Sellised stereotüüpsed uskumused, argiklišeed ja -fraasid ning üldised seisukohad, millele viitab argiarvamustega seoses Virtanen (1994: 20-52), puudutavad Perekoolis nii rasedust, sünnitust, meditsiini, laste käitumist, peresuhteid kui ka muid eluvaldkondi.

Aastal 2004 esitati foorumites küsimus selle kohta, milliseid linnalegende Perekoolis leidub. Küsimusele tulid vastuseks peamiselt argiarvamused ja stereotüübid. Vastused võtsid väga hästi kokku Perekoolis levivad seisukohad, mida päevast päeva produtseeritakse. Mõned kirjutajad püüdsid ka huumori ja ülepaisutamise abil väljendada foorumites levivaid uskumusi. Sellest võib järeldada, et inimesed siiski tajuvad, et sellistes üldistustes on tõele vastavat enamasti väga vähe, kuigi nad ei oska neid žanriliselt määratleda.

Kui sulle ei meeldi imetada, siis sa ei vääri ema austavat nimetust ja imetama pead sa nii kaua, kui LAPS TAHAB (http://w.perekool.ee/foo$\mathrm{rum} / \mathrm{read}$.php?f=6\&i=565456\&t=565192).

Kui laps hakkab vara käima, siis ta on teismelisena vigane ja kui normaalsel ajal, siis on nõme neuroloog. Kui laps hakkab hilja käima, siis lohutatakse, et iga laps ei arenegi kiiresti (http://w.perekool.ee/foorum/ read.php?f=7\&i=496893\&t=496595). 
Artiklis “Tarbetarkusest argiarvamuseni, vahel vanasõnaks välja?" (1997) liigitab Risto Järv argiarvamuste alla ainult sellised kõneaktid, kus väitele järgneb käitumise põhjendus, vastasel juhul on tegemist lihtsalt tavaga. Toodud näited mahuvad seega nii argiarvamuste kui ka kitsamalt steretüüpide alla. Argiarvamusi võib rakendada peamiselt kas praktiliste käitumisjuhistena või märgivad need kirjutaja enese arvamust, mis lähemal vaatlusel kordab või varieerib kusagil varem kuuldut (Virtanen 1994: 66-76). Risto Järv kirjutab, et uurijad on märkinud, et vanasõnu kasutades väheneb ütleja vastutus ja suureneb öeldu kaalukus. Sama mõtet püüab ta laiendada ka argiarvamustele, väites, et üldistades olemasolevaid fakte omandab argiarvamus niiviisi suurema tõeväärtuse ning kui see tõde on väljendatud kollektiivse pärimuse vahendusena, muutub argiarvamus varasemast väärtuslikumaks (Järv 1997: 30, 35). Sellist tähelepanekut rakendades võib märgata ka, et Perekoolis kinnitavad palju kirjutajad oma mõtteid just argiarvamustega, püüdes lisada neile suuremat kaalu - oma arvamuse esiletõstmiseks ja väärtustamiseks ning teiste veenmiseks toetutaksegi sealses keskkonnas üldistele ja tinglikele seisukohtadele.

Kõhukott tekitab kõvera selja (Palun rääkige pk-s liikuvaid linnalegende? (Beebi)).

Solaariumis käies läheb lootevesi keema (Palun rääkige pk-s liikuvaid linnalegende? (Lapse ootamine)).

Perekoolis esineb ka vanasõnu, kõnekäände ja keerdküsimusi. Üldiselt liiguvad need tekstide sees ning kahte esimest žanrit kasutatakse oma kõne illustreerimiseks sageli. Keerdküsimusi esitatakse tavaliselt eraldi teemaalgatusena või siis mõne muu meelelahutusliku teema raames.

Järgnevalt toon näiteks ühe teemaalgatuse, kus paluti kirjutada vanasõnu sünnitusmajadest (Vanasõnu sünnitusmajadest - http://w.perekool.ee/foorum/ read.php?f=5\&i=35813\&t=35509). Teema oli suhteliselt populaarne - see aitas lisaks meelelahutusele ka nalja heita meditsiini ja ämmaemandate üle. Suurem osa loodud vanasõnadest või ütlustest on teiste traditsiooniliste vanasõnade paroodiad, kuid sellele vaatamata kohati üsna tabavad:

Rumal rase ees - vilets sünnitus taga; Loll saab sünnitusmajas ka peksa; Las rasedad hauguvad, laud on sünnitussaalis edasi; Mis täna lõigatud, see homme hooleta, võib ka: miss - täna lõigatud, homme meheta; Kel kätt, sel kääri; Mida enam arste valves, seda enam nad kaagutavad; Liikuv sünnitaja ei sammaldu; Kui kodus sünnitanu mees sünnitusmajja jõudis, olid isikukoodid juba jagatud. 
Samuti esineb foorumis hulgaliselt aforisme, võrdlusi või siis vanasõnade ja kõnekäändude paroodiaid.

Soeng sassis = plahvatus makaronivabrikus; Töö seisab, palk jookseb ja pudel käib ringi; Raske on lennata kotkana, kui sa töötad koos kanadega; Kui Ants tahab, võib ta oma välimust muuta. Ants on korduvalt ennast rihmaks joonud.

\subsection{Anekdoodid või naljandid}

Inimesed käivad Perekooli foorumites end nii positiivsete kui ka negatiivsete kommentaaride kaudu välja elamas. Lisaks kaasvestlejate halvustamisele ja kritiseerimisele jagatakse kaaslastega ka anekdoote ja lõbusaid seiku laste või enda elust. Aeg-ajalt esineb erinevates foorumites ka kellegi fiktiivse tegelase poolt järjejuttude kirjutamine, mis peaksid parodeerima päris elu.

Üks sellistest oli näiteks Birgith, kes sattus Perekooli Lapse ootamise foorumisse 2004. aasta juunis. Birgith kirjutas oma rasedusest ja esitas palju küsimusi. Kirjutades oma jutud naiivselt ja kohati vulgaarset sõnavara kasutades, võitis ta kohe nii pooldajaid kui vastaseid. Igal juhul oodati tema uusi teemasid tõenäoliselt sama suure huviga kui loodeti tüütust foorumi risustajast vabaneda. Birgithi fenomeniks võib pidada kahtlemata tema naljakaid lähenemisi ja lahendusi nii tõsisele asjale, kui rasedus on lapse ootajatele ning teisalt paljude tabude rikkumist ja avalikult rääkimist intiimsetel teemadel, nende toomist foorumisse ning muutmist osaks oma verbaalsest performance'ist ja näilikust enesepaljastusest. Nagu võis lugeda Birgithi teemade kommentaaridest, mõjub selline nali kohati värskendavalt ja seega sai kirjutaja siit uut indu juurde, kui teda esile tõsteti ja tema kirjutistele edu sooviti. (Reinaus 2007:50)

Kalla tahtis teha mulle keisrilõike

Autor: birgith(23nädal)

Kuupäev: 25-10-04 18:01

Eile oli peale seksi sellised gaasid, et kalla arvas, et laseme paugubeebi lageda taeva alla. Kuna sünnitegevust me ise ei suutnud alustada, siis kalla arvas, et tal teeb mulle keisri. Kalla tegi kõhtu ilusa suure augu ja sellise päraka suuruse. Kalla arvas, et sellest, et ehk piisab. Kuid peale imeliku leha ei olnud paugubeebist haisugi. Ainult sisin ja hais. Nii, et pole parata, jään siia leheküljele edasi. Kalla on nii nunnu ja armas ja suvel läks ta nii pruuniks ponksiks. Fakkk, ma olen häppi, naised! (http://w.perekool.ee/foorum/read.php?f=2\&i=463740\&t=463740). 
Teine selline mulle teadaolev juhtum leidis aset aastatel 2005-2006 ning oli seotud Pereelu foorumis figureerinud Voldemar-Augusti kasutajanime taga oleva isikuga. Tema postitused olid peamiselt filosoofilist laadi mõtisklused, kus ta püüdis tavapäraste olmeliste situatsioonide ja nähtuste kaudu edasi anda mingit üldisemat tõde või pedagoogilist mõttetera. Paljudel juhtudel on ta käsitlenud ka seksuaalset temaatikat. Lugude või arvamusavalduste pealkirjad on tal sageli valitud teadlikult abstraktsed - Autosõit, Tõmmata ja lükata, Arvutimäng, Tomat, Ö̈bik, Kookonis jne.

Tema kirjutistest jäi siiski selgusetuks, kas ta kirjutas neid foorumisse puhtalt meelelahutuslikul eesmärgil või soovis kaaslasi šokeerida või provotseerida. Erilist tähelepanu ta ei pälvinud. Uurijana olen ta kirjutised liigitanud sisust lähtuvalt meelelahutusliku funktsiooni alla.

Plastmassist karp

Autor: Voldemar.August

Kuupäev: 02-09-05 20:03

Sattusin koduse remondi käigus vastamisi elektrijaotus plastmassist karbiga, mida mul kuidagi sulgeda ei õnnestunud. Pressisin ja pressisin, kuid karbikaas ainult nagises, kuid kinni ei jäänud. Juba peaaegu lootuse kaotanud,lükkasin veel korra õrnalt näpuotsaga ja ennäe karp läks kinni. Siis sain aru, et ma sellepärast soovitud eesmärki ei saavutanud, et olin selle nimel pingutanud liiga kõvasti (http://w.perekool.ee/foorum/ read.php?f=3\&i=1052947\&t=1052947).

Väga sageli esitatakse foorumeis ka laste suust pärinevad nalju või lihtsalt lastega seotud lõbusaid lugusid. Sageli kutsub üks selline nali esile ka teistes lugejais soovi mõni naljakas juhtum kirja panna ja nii saab alguse iselaadne virtuaalne naljade esitamine.

Nalja sai meil praegu

Autor: linnalapsed

Kuupäev: 20-07-05 11:50

3-ne ja 5-ne mängisid äsja mingit oma mängu. Kui tuppa astusin oli 5-sel kiiver peas, mängumobla käes ja juhatas kujuteldavat kiirabi: "Võtke siia mootorratta kõrvale, mul lehmal ja karul tuleb verd!”(http://w.perekool.ee/ foorum/read.php?f=7\&i=692133\&t=692133).

Nagu selgub järgnevatest näidetest, ei esitata mitte ainult oma laste nalju, vaid ka selliseid, mis Interneti vahendusel levivadki. 
Loomade keha asub tavaliselt pea taga ja käpad tolknevad allpool. (6a Katja)

Aafrika lehmad söövad banaane, aga kui nad on ahvid, siis elavad nad dzunglis ja otsivad kirpe. (5a Christel)

Nina on tegelikult hingamise lihas. Aga seda võib kasutada ka tati vedamiseks. (6a Emil)

(http://w.perekool.ee/foorum/read.php?f=7\&i=598937\&t=598937).

Pereelu foorumites, mis on pealiskaudsemad kui lastega seotud foorumid, on anekdootide ja muu meelelahutusliku elemendi osakaal suurem. Lisaks anekdootidele esineb foorumeis linke naljakate animatsioonide või fotodega. Anekdootide üldine sisu on seotud sageli seksuaalsusega. Lingid, mida üksteisele saadetakse, on vahel koguni pornograafilise sisuga.

Teinekord kirjutatakse üles ka nalju, mis on juhtunud inimeste endiga, palutakse kirjutada huvitavaid ütlemisi või muud sellist.

Re: Vajun kohe häbi pärast maa alla...

Autor: megairw

Kuupäev: 26-10-05 23:30

mu tuttaval suri onu ja siis ta lasi teha hauakivi. ütles,et kirjutage kivile "Puhka rahus" ja see tekst võiks olla mõlemal küljel. Aga see hauakivitegija oli vist venelane, igaljuhul umbkeelne. Läks siis kivile järgi ja sinna peale oli kirjutatud:"Puhka rahus mõlemal küljel" (http://w.perekool.ee/ foorum/read.php?f=3\&i=1134567\&t=1134185).

\subsection{Muistendid ja memoraadid}

Usundilisi muistendeid, mis annavad edasi üleloomulikku kogemust, leidub Perekoolis peamiselt seoses rasedusaegsete uskumuste täideminekuga, unenägudega või mõne muu üleloomuliku nähtusega. Eelkõige esinevad foorumites memoraadid, kuid sageli räägitakse ka mõne tuttava või sugulasega juhtunud sündmustest. Memoraadid on peamiselt kogemuslood, milles kirjutaja annab edasi temaga toimunut. Tihtipeale on lood seotud lapse soo etteaimamisega või selle unes nägemisega. Mõnikord küsitakse lihtsalt teiste arvamust, kuid vahel kirjutatakse nähtavasti üksnes selleks, et seda kaaslastega jagada.

Beebi ja tema surnud vend!

Autor: Tibulille ema

Kuирёev: 18-12-04 21:19 
Mu sõbrannal suri poisitita kolmandal elupäeval pärast sündi. Ta otsustas kahe-kolme kuu pärast kiiresti uuesti rasestuda kuigi arstid soovitasid aasta vahet pidada. Sündiski uus poisslaps ja ta oli täpselt sama nägu mis tema õnnetult surnud vend. Sõbranna oli sellest rabatud... (http:// w.perekool.ee/foorum/read.php?f=6\&i=565515\&t=564938).

Sageli annab loo kirjutamisele tõuke näiteks küsimus, milliseid üleloomulikke asju on teiega juhtunud vms, millele inimesed oma lugudega vastavad.

Maja vaimudega??

Autor: peetjake

Kuupäev: 16-01-06 18:18

nii. minu mehe vanemate naabermajas kunagi juhtus midagi majaperemehega. Igasthes leiti ta sealt hulk aega hiljem surnult, suust oli verd jooksnud jne. Peale seda majas kummitas. Majal oli peale sade meest mitu omanikku, aga keegi seal sees ei elanud. Niikui osteti, kohe ka mü̈̈di. Naljapärast olid paar "kõva meest" otsustanud, et veedavad seal majas ühe öö. Igastahes jooksid nad hirmunult öösel majast välja. Selles majas käidi igat moodi kurje vaime välja ajamas. Miskit ei aidanud. Keegi preester oli öelnud, et ainus võimalus on maja lammutada (oli muidu korralik telliskivimaja pääskülas) Täna elab seal noor perekond. Tõsi küll, mitte selles majas, sest maja lõpuks lammutatigi maha ja ehitati uus (http://w.perekool.ee/foorum/read.php?f=3\&i=1275153\&t=1274642).

Perekooli keskkonnas võib kohata ringlemas ka kaht teksti, mida siinkohal sobib paigutada ehk hoiatusmuistendite alla. Nende eesmärk on mõjutada naisi mitte aborti tegema. Ühel juhul on tegemist päevikuvormiga - arenev loode kirjutab oma füüsilisest arengust ja armastusest ema vastu. Minategelane kirjeldab, milliseid muutusi ta iga nädal läbi teeb ja kuidas ta ootab kohtumist oma emaga. Tema nö päevik lõppeb lakoonilise tõdemusega: Täna lasi ema mu tappa.

Teine tekst on luulevormis ega keskendu mitte niivõrd lapse arengule, kuivõrd tema lootusele näha puid, lilli ja oma mänguasju. Sissejuhatavale osale järgneb kohe ema haiglasseminek, kus loode küsib emalt, kuhu nad lähevad ja hiljem, miks talle haiget tehakse. Ka see tekst lõppeb loote surmaga, kus ta veel kuni lõpuni kinnitab, et armastab oma ema.

Perekoolis ei võeta selliseid tekste tavaliselt kuigi hästi vastu, kuid aegajalt avaldatatakse neid ikka ja jälle mõne teema all või siis täiesti omaette teemana. Et mõlemad lood on emotsionaalsed ja südamlikud, võib oletada, et see on üks põhjusi, miks usutakse, et see mõjutab aborti plaanivaid naisi oma otsusest loobuma. 


\section{Kokkuvõte}

Nagu suuremat osa virtuaalsest keskkonnast, nii iseloomustab ka Perekooli foorumeid erineva folkloorse ainese suur kontsentratsioon. Keskkonna eripäraks on see, et seal levivad uskumused peamiselt põlvkonna-siseselt. Eakate sugulaste või tuttavate ütlusi arvestatakse meelsamini siis, kui keegi eakaaslastest on kirjutanud seda kinnitava isikliku kogemusloo, siis võidakse kogemuslugu võimaliku variandina arvesse võtta.

Paljudel juhtudel sõltub pärimusliku ainese omaksvõtt foorumeis kontekstist - millega seoses teema püstitatakse ja milliseid pärimusega seotud valdkondi puudutatakse, samuti on olulised kirjutaja retoorilised oskused. Väljend vanarahvatarkus võib iseenesest olla keskkonnas nii negatiivse kui positiivse värvinguga.

Eri folkloorižanreid leidub foorumites rohkesti. Esikohal on usundilise maailmaga seotud folkloor - uskumusteated, memoraadid ja muistendid. Teiseks on populaarne meelelahutuslik materjal - anekdoodid, naljad, animatsioonisd, pildilingid jne. Perekooli ajaviitelisele funktsioonile viitab ka see, et isegi usundilised teemad pannakse paljudel juhtudel foorumisse just meelelahutuslikul eesmärgil.

Foorumid aitavad pärimuse levikule kaasa, muutes inimeste teadvuses oleva latentse materjali arutelude läbi aktuaalseks. Seetõttu võib mõni arhailine uskumus veel tänapäevalgi tekitada inimestes küsimusi ja kõhklusi. Võib öelda, et Perekool on ise nii ennete ja uskumuste taastootja ning ka uute nähtuste levitaja. Nii folkloori arengu kui ka selle žanride uurimisel on Perekooli vestlusring väga tänuväärne allikas, sest sealses keskkonnas liikuv materjal on paljude silmis aktuaalne.

\section{Kirjandus}

Brunvand, Jan Harold 1999. 21. 09. 1999 CNN-i koduleheküljel toimunud interaktiivse intervjuu transkriptsioon (http://cnn.com/chat/transcripts/jan.harold.brunvand.html - 30. jaanuar 2008).

Coomber, Ross 1997. Using the Internet for Survey Research. Sociological Research Online 2: 2. (http://www.socresonline.org.uk/socresonline/2/2/2.html - 30. jaanuar 2008).

Dicks, Bella \& Mason, Bruce 1998. Hypermedia and Ethnography: Reflections on the Construction of a Research Approach. Sociological Research Online 3: 3 (http:// www.socresonline.org.uk/socresonline/3/3/3.html - 25. mai 2007). 
Jordan, Rosan Augusta 1997. Computer Folklore. Green, Thomas A. (toim). Folklore. An Encylopedia of Beliefs, Customs, Tales, Music and Art 1: 140-142. Santa Barbara, California; Denver, Colorado \& Oxford, England: ABC-Clio.

Järv, Risto 1997. Tarbetarkusest argiarvamuseni, vahel vanasõnaks välja? Hiiemäe, Mall \& Oras, Janika (toim) Maa ja ilm (Pro Folkloristica V). Tartu: Eesti Kirjandusmuuseum, lk 26-42.

Lampel, Joseph \& Bhalla, Ajay 2007. The role of status seeking in online communities: Giving the gift of experience. Journal of Computer-Mediated Communication, 12 (2): 5 (http://jcmc.indiana.edu/vol12/issue2/lampel.html - 25. mai 2007).

Mikkor, Marika 2000. Sünnikombestikust linnas ja maal. Akadeemia 4-5, lk 806-847 \& 1017-1044.

Oja, Anni 2005. Sotsiaalsed võrgustikud, keel ja identiteet Eesti Interneti-ruumis. Käsikiri autori valduses.

PK = Perekool . www.perekool.ee.

Reinaus, Reeli 2007. Enesepresentatsioon virtuaalses kogukonnas sünnituslugude ja Perekooli foorumi kommentaaride näitel. Magistritöö. Tartu: Tartu Ülikool. Käsikiri TÜ raamatukogus.

Rheingold, Howard 1998. Virtual Community (http://www.rheingold.com/vc/book/ - 25. mai 2007).

Ridings, Catherine M. \& Gefen, David 2004. Virtual Community Attraction: Why People Hang Out Online. Journal of Computer Mediated Communication, 10 (1) 11. 2004. (http://jcmc.indiana.edu/vol10/issue1/ridings_gefen.html - 25. mai 2007).

Runnel, Pille 1999. Välitööde võimalikkusest internetis: [internet kui uurimisobjekt ja kultuuriuurija töövahend]. Kalmre, Eda (toim). Kuuldust-nähtust. Tänapäeva folkloorist IV. Tartu, lk 13-30.

Seljamaa, Elo-Hanna 2000. Elektronkirjade teel levivast Interneti-folkloorist. Proseminaritöö. Tartu: Tartu Ülikool (http://www.fillu.edu.ee/sisu.php?id=41\&teema=5 - 22 . november 2007).

Suler, John R. 1996a. The Basic Psychological Features of Cyberspace. The Psychology of Cyberspace (http://www.rider.edu/ suler/psycyber/index.html - 5. märts 2008).

Suler, John R. 1999. One of Us: Participant Observation Research at the Palace. The Psychology of Cyberspace (http://www.rider.edu/ suler/psycyber/partobs.html - 5. märts 2008).

Suler, John R. 2000. Hypotheses about Online Text Relationships. The Psychology of Cyberspace (http://www.rider.edu/ suler/psycyber/textrel.html - 5. märts 2008).

Thomsen, Steven R. \& Straubhaar, Joseph D. \& Bolyard, Drew M. 1998. Ethnomethodology and the Study of Online Communities: Exploring the Cyber Streets. Proceedings IRISS 1998, Bristol, UK, March 25-27 (http://www.sosig.ac.uk/iriss/papers/paper32.htm -6. juuni 2007). 
Traat, Merike 1990. Tänapäeva sünnikombestikust. Rasedusaegsed uskumused. Diplomitöö. Tartu: Tartu Ülikool.

Virtanen, Leea 1994. Punatukkaiset ovat intohimoisia. Arjen uskomuksia. Porvoo: WSOY.

Wallace, Patricia 2002. Internetipsühholoogia. Rollid elus ja internetis. Tallinn: Valgus.

\section{Summary}

\section{The Formation, Development and Manifestations of Lore Material in Estonian Family Forum}

\section{Reeli Reinaus}

Key words: folklore, folklore genres, Internet, folk wisdom, transmitting of lore

The article discusses the spread, reception and manifestations of folklore in online environment. The material under discussion has been drawn from the forum of the online Estonian family portal www.perekool.ee

The first part of the article explores the spread and development of lore material and related behavioural patterns in the forum. The author also points out the ways in which the attitudes towards a homogeneous corpus of material differ in terms of the mode of presentation.

Since today virtual communities have become the primary form of social interaction for many people, the place where they spend most of their day, these environments naturally involve the creation and transmitting of folkloric information.

The attitude towards folkloric material in this particular forum may depend on the context and the background knowledge of receivers: folklore is both ridiculed and valued. Often the attitudes depend on how, by whom and in relation of what it is presented. It is noteworthy that beliefs are spread in the forum within one generation. While formerly beliefs were transmitted from older generation to the younger, the older generation and their worldview, which is perceived as irrational from the viewpoint of modern science, is no longer considered trustworthy. However, if it is presented as someone's personal experience story, the belief is accepted as an alternative way.

The second part of the article observes the forms and functions of material that could be categorised as folkloric. The forums feature a variety of folklore genres: folklore related to the religious world (belief accounts, memorates, and legends) and entertaining material. The entertaining function of the forum becomes evident even in the inclusion of religious themes for entertaining purposes.

Forums of active use, such as www.perekool.ee, help to spread folklore by actualising the latent material in people's knowledge. This is why some archaic beliefs may generate questions and doubts even in modern times. The family forum Perekool thus becomes the reconstructer of omens and beliefs as well as the distributor of new phenomena. 